\title{
Diurnal changes in seawater carbonate chemistry speciation at increasing atmospheric carbon dioxide
}

\author{
K. G. Schulz $\cdot$ U. Riebesell
}

Received: 31 December 2011/Accepted: 16 May 2012/Published online: 13 June 2012

(C) The Author(s) 2012. This article is published with open access at Springerlink.com

\begin{abstract}
Natural variability in seawater $\mathrm{pH}$ and associated carbonate chemistry parameters is in part driven by biological activities such as photosynthesis and respiration. The amplitude of these variations is expected to increase with increasing seawater carbon dioxide $\left(\mathrm{CO}_{2}\right)$ concentrations in the future, because of simultaneously decreasing buffer capacity. Here, we address this experimentally during a diurnal cycle in a mesocosm $\mathrm{CO}_{2}$ perturbation study. We show that for about the same amount of dissolved inorganic carbon (DIC) utilized in net community production diel variability in proton $\left(\mathrm{H}^{+}\right)$and $\mathrm{CO}_{2}$ concentrations was almost three times higher at $\mathrm{CO}_{2}$ levels of about $675 \pm 65$ in comparison with levels of $310 \pm 30 \mu \mathrm{atm}$. With a simple model, adequately simulating our measurements, we visualize carbonate chemistry variability expected for different oceanic regions with relatively low or high net community production. Since enhanced diurnal variability in $\mathrm{CO}_{2}$ and proton concentration may require stronger cellular regulation in phytoplankton to maintain respective gradients, the ability to adjust may differ between communities adapted to low in comparison with high natural variability.
\end{abstract}

\section{Introduction}

There is a considerable natural variability in seawater carbonate chemistry speciation, namely carbon dioxide $\left(\mathrm{CO}_{2}\right)$,

Communicated by S. Dupont.

K. G. Schulz $(\varangle) \cdot$ U. Riebesell

Helmholtz Centre for Ocean Research (GEOMAR),

Düsternbrooker Weg 20, 24105 Kiel, Germany

e-mail: kschulz@geomar.de bicarbonate $\left(\mathrm{HCO}_{3}^{-}\right)$, carbonate ion $\left(\mathrm{CO}_{3}^{2-}\right)$ and proton $\left(\mathrm{H}^{+}\right)$ concentration, as well as $\mathrm{pH}$ and calcium carbonate saturation state $(\Omega)$. This is mainly caused by changes in temperature and biological activities such as photosynthesis, respiration, nutrient utilization, remineralization and calcium carbonate precipitation and dissolution. Variability is on inter-annual, seasonal and diurnal time scales.

For instance, photosynthesis and respiration have been reported to drive diurnal variations in $\mathrm{pH}$ of up to one unit in eutrophic lakes [compare Maberly (1996)]. In seawater, diurnal fluctuations in $\mathrm{pH}$ are usually considerably smaller, ranging from 0.1 units in spring in the Bay of Calvi in the Mediterranean (Frankignoulle and Bouquegneau 1990) to 0.15 in autumn in the Bay of Bengal in the Indian Ocean (Subramanian and Mahadevan 1999) and up to 0.5 in a Kelp forest close to the Kerguelen Archipelago in the Southern Ocean in austral summer (Delille et al. 2009). In coral reefs, calcium carbonate precipitation and dissolution are impacting carbonate chemistry speciation apart from photosynthesis and respiration, and measured $\mathrm{pH}$ changes range from 0.16 to 0.78 units [Ohde and van Woesik 1999; Frankignoulle et al. 1996. Tides, however, may also contribute to diurnal changes considerably (Manzello 2010)].

Similarly, seasonal variations differ from region to region with highest $\mathrm{pH}$ variability in low-buffered eutrophic systems such as lakes or the Baltic Sea with up to 3.2 and $0.7 \mathrm{pH}$ units, respectively (Maberly 1996; Thomsen et al. 2010). Lowest seasonal variability is found in well-buffered oligotrophic open ocean waters with an average of about 0.022 at HOT, the Hawaii Ocean Time Series, and $0.055 \mathrm{pH}$ units at ESTOC, the European Station for Time Series in the Ocean [adapted from Dore et al. (2009) and GonzálezDávila and Santana-Casiano (2011), respectively].

On top of the natural carbonate chemistry variability, the ongoing release of anthropogenic $\mathrm{CO}_{2}$ is shifting speciation 
toward higher concentrations of $\mathrm{CO}_{2}, \mathrm{HCO}_{3}^{-}$and $\mathrm{H}^{+}$, reducing $\mathrm{pH}, \mathrm{CO}_{3}^{2-}$ concentrations and calcium carbonate saturation state. Reduced $\mathrm{CO}_{3}^{2-}$ ion concentrations lower the buffer capacity of seawater, thus considerably increasing natural variability (Frankignoulle 1994).

Here, we assess this phenomenon experimentally by reporting on diurnal variations in seawater carbonate chemistry speciation during a phytoplankton bloom event in five mesocosms manipulated for different seawater $\mathrm{CO}_{2}$ levels, ranging initially from about $370 \mu$ atm to $1250 \mu \mathrm{atm}$. These levels are representative for current day conditions and, according to different emission scenarios (Farquhar et al. 2001), the upper limits expected at the end of this century, respectively. Furthermore, a modeling exercise demonstrates that changes in the magnitude of natural variability are expected to differ between oceanic regions.

\section{Materials and Methods}

\section{Experimental setup}

In May 2009, six off-shore mesocosms were deployed by the research vessel R/V ALKOR at Boknis Eck in the Kiel Bight in the western part of the Baltic Sea $\left(\sim 54.53^{\circ} \mathrm{N}\right.$, $\left.\sim 10.03^{\circ} \mathrm{E}\right)$. The Kiel Off-Shore Mesocosms for future Ocean Simulations (KOSMOS) were moored in clusters of three in about 1 nautical mile distance to the shoreline. For a detailed description of KOSMOS construction and operation, see Riebesell et al. [in prep.]. Briefly, 13.5-mlong and 2-m-diameter thermoplastic polyurethane bags were attached to 7-meter-long floating structures, rising about $1.5 \mathrm{~m}$ out of the water, and unfolded to about $12 \mathrm{~m}$ depth. For this procedure, flaps at the bottom of the bags were opened to ensure thorough filling. Then, the upper part of the bags was pulled about $1 \mathrm{~m}$ underneath the water surface to allow for seawater exchange at both ends, minimizing any initial differences between the enclosed water masses of the six mesocosm bags. After about two days, differences in profiles of salinity, temperature, turbidity, chlorophyll $a(\mathrm{Chl} a)$ and $\mathrm{pH}$ were found to be negligible as measured by multiple CTD casts (see "CTD operation" section for details). A team of divers then closed the flaps at the bottom of the bags, while a second group quickly retrieved the upper part of the bags from $1 \mathrm{~m}$ depth and secured it $1.5 \mathrm{~m}$ above the water surface to the floating structures, thereby enclosing seawater (in theory $37.7 \mathrm{~m}^{3}$, but see below) with very similar starting conditions in all six bags.

The seawater carbonate system in the six bags was manipulated gradually over three days by injections of certain amounts of $\mathrm{CO}_{2}$-enriched filtered seawater $(20 \mu \mathrm{m})$.
This was achieved by lowering a dispersal device to $12 \mathrm{~m}$ depth and pulling it up again to the surface for several times. Pumping of the $\mathrm{CO}_{2}$-enriched seawater through the dispersal device then evenly distributed the $\mathrm{CO}_{2}$ addition between 0 and $12 \mathrm{~m}$. The addition was such that on day $\mathrm{t} 0$ (May 21, 2009) 251 was added to mesocosm M5 and 501 each to M1, M3, M4 and M6, while M2 remained unperturbed. On the next day, another 251 was added to M3, 501 to M4, 701 to M6 and 801 to M1. On the third day, only M1 received another 251 . Also, on that day, a hole was discovered in the bag of M1, allowing the inflow of surrounding seawater. M1 was therefore excluded from the experiment. The $\mathrm{CO}_{2}$ enrichment changed the fugacity of carbon dioxide $\left(\mathrm{fCO}_{2}\right)$ in seawater to about 1,265 \pm 120 $\mu$ atm in M6, 1,080 $\pm 100 \mu \mathrm{atm}$ in M4, $815 \pm 80 \mu \mathrm{atm}$ in $\mathrm{M} 3$ and $600 \pm 60 \mu \mathrm{atm}$ in M5 on day $\mathrm{t} 1$, while $\mathrm{fCO}_{2}$ in M2 remained close to that in the surrounding seawater at about $370 \pm 40 \mu \mathrm{atm}$. Due to considerable biological activity, $\mathrm{fCO}_{2}$ ranged from about $675 \pm 65,605 \pm 60$, $520 \pm 50,420 \pm 40$ to $310 \pm 30 \mu \mathrm{atm}$ in mesocosms M6, M4, M3, M5 and M2, respectively, on day t4 (at about 7:00), the day of the diurnal cycle. For carbonate chemistry calculations and uncertainty estimates, see "Carbonate chemistry measurements and calculations" section. Addition of $\mathrm{CO}_{2}$-enriched seawater changes the concentrations of dissolved inorganic carbon (DIC) while leaving total alkalinity (TA) constant, and is therefore perfectly simulating ongoing ocean acidification (Schulz et al. 2009; Gattuso et al. 2010).

Similar to previous mesocosm $\mathrm{CO}_{2}$ perturbation studies (e.g., Engel et al. 2005; Schulz et al. 2008), a phytoplankton bloom was initiated by adding nitrate and phosphate to the bags on day $\mathrm{t} 0$, aiming to increase nitrate concentrations from below detection limit to $10 \mu \mathrm{mol} 1^{-1}$ and phosphate from initial concentrations of about 0.15 to $0.65 \mu \mathrm{mol} 1^{-1}$. Since the exact volumes of the bags were unknown (due to the flexible walls), nutrients were added in two steps. The first addition was based on a conservative estimate, significantly smaller than the theoretical volume of $37.7 \mathrm{~m}^{3}$. Measured nutrient concentrations in depthintegrated (0-9.5 m) samples collected with an Integrating Water Sampler, IWS (HYDROBIOS), a couple of hours after the addition revealed that water volume was indeed larger and differed between mesocosms by up to $20 \%$. Nitrate and phosphate were therefore added a second time, in different amounts to each mesocosm, on the morning of day $\mathrm{t} 2$ to achieve the targeted addition of $10 \mu \mathrm{mol} 1^{-1}$ of nitrate and $0.5 \mu \mathrm{mol} 1^{-1}$ of phosphate. However, as nutrients are relatively quickly taken up by marine phytoplankton (1.2-1.6 $\mu \mathrm{mol} 1^{-1}$ of nitrate between day t0 and day $\mathrm{t} 1$ ), they are not ideal tracers of mesocosm volume. Therefore, it is possible that slightly different nutrient concentrations were added to each mesocosm. 
Measurement of nitrate and phosphate followed the methods described in Hansen and Koroleff (1999).

Carbonate chemistry measurements and calculations

Carbonate chemistry was calculated from $\mathrm{pH}$ and total alkalinity (TA) with the temperature- and salinity-dependent stoichiometric equilibrium constants for carbonic acid determined by Mehrbach et al. (1973) as refitted by Lueker et al. (2000). TA was determined by potentiometric titration as described in Dickson et al. (2003) and (2007) on depth-integrated (0-9.5 m) water samples collected with depth-integrating water samplers (IWS Integrating Water Sampler, HYDROBIOS) in each mesocosm and the surrounding water about every other day. $\mathrm{pH}$ profiles were measured by means of a CTD-mounted sensor (see "CTD operation section and "pH correction" section for details).

For calculations of reported $\mathrm{fCO}_{2}$ levels on day $\mathrm{t} 1$, mean water column (0-9.5 m) pH was derived from respective profiles (for $\mathrm{pH}$ correction, see " $\mathrm{pH}$ correction " section) on this day and used together with linearly interpolated TA values derived from depth-integrated $(0-9.5 \mathrm{~m})$ TA measurements in each mesocosm on days $\mathrm{t} 0$ and $\mathrm{t} 2 . \mathrm{fCO}_{2}$ levels reported for day $t 4$ were derived analogously. Note that TA changed only marginally during the 14 days of the experiment (10-20 $\left.\mu \mathrm{mol} \mathrm{kg}^{-1}\right)$, mainly due to nitrate utilization and evaporation.

DIC profiles were calculated from corrected $\mathrm{pH}$ profiles (see "pH correction" section for details) and measured depth-integrated (0-9.5 m) TA (on day t5), assuming that total alkalinity was constant with depth. This assumption is supported by the even salinity distribution in the upper 9.5 $\mathrm{m}$ of the mesocosms (compare Fig. 1) and negligible contributions of calcifying organisms (D. Rossol, GEOMAR, pers. comm).

Overall uncertainties in calculated $\mathrm{fCO}_{2}$ and DIC were determined according to Dickson (2010) from estimated uncertainties in $\mathrm{pH}(0.04 \mathrm{pH}$ units $)$ and total alkalinity $\left(3 \mu \mathrm{mol} \mathrm{kg}{ }^{-1}\right)$. Uncertainties in calculated $\mathrm{fCO}_{2}$ ranged between 40 and $120 \mu \mathrm{atm}$, while those in DIC between 9 and $12 \mu \mathrm{mol} \mathrm{kg}{ }^{-1}$. These uncertainty estimates are probably upper limits as coulometric DIC measurements on days $\mathrm{t} 2$ and $\mathrm{t} 13$ are only $2-5 \mu \mathrm{mol} \mathrm{kg}{ }^{-1}$ off the calculated values. Note that estimated uncertainties are the uncertainties in absolute values/concentrations and that the uncertainties in changes over time (e.g., pH or DIC) relative to starting conditions are less. This is reflected in the relatively smooth increase in $\mathrm{pH}$ during the night in all mesocosms, suggesting an uncertainty in $\mathrm{pH}$ change of about 0.01 , corresponding to an uncertainty in DIC change of about $3 \mu \mathrm{mol} \mathrm{kg}{ }^{-1}$, or even less (for precision of the $\mathrm{pH}$ sensor, see next section).

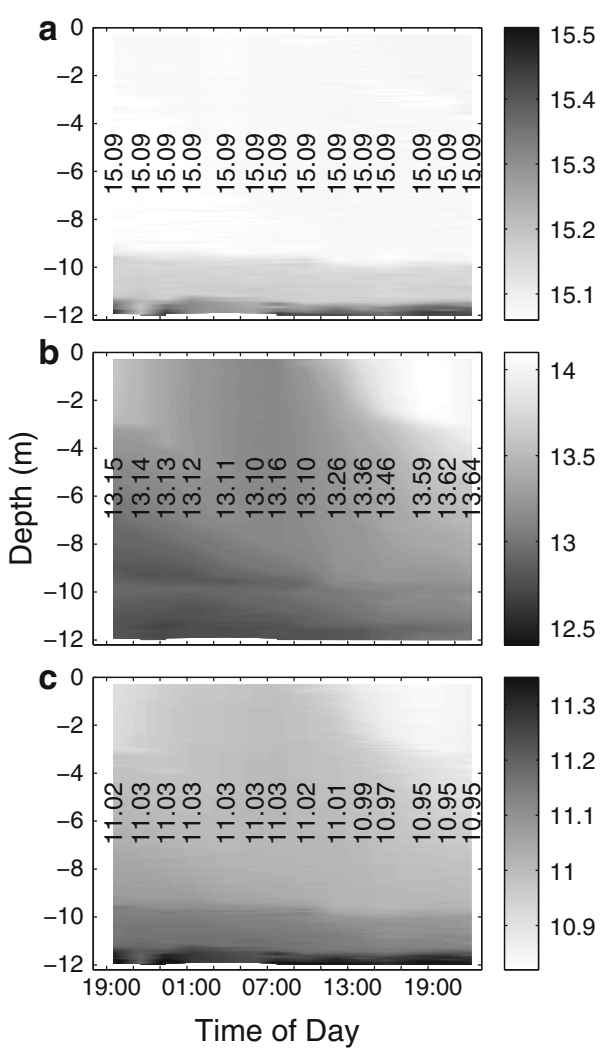

Fig. 1 Measured vertical distribution of salinity (a), temperature (b) and density anomaly $\sigma_{\mathrm{T}}$ (c) with time in mesocosm M4. Temperature is reported in degrees Celsius and $\sigma_{\mathrm{T}}$ in $\mathrm{kg} / \mathrm{m}^{3}$. Vertical numbers give mean values of the respective parameter in the water column $(0.3-11 \mathrm{~m})$ at each cast. Salinity, temperature and density changes with time are virtually identical in all mesocosms

\section{CTD operation}

Profiles of salinity, temperature, turbidity, $\mathrm{Chl} a$ and $\mathrm{pH}$ were collected every two hours starting at 19:00 on day t3 with a cast in the Baltic close to mesocosm M1, followed by M1 (although excluded), M2, M3, M4, M5 and M6. The last CTD cast was on the following day at 22:30 in mesocosm M6. The CTD (memory probe CTD 60M, Sea and Sun Technology) was equipped with an ADM 7-pole conductivity cell $(\sim 0.02$ salinity units accuracy and $\sim 0.005$ salinity units precision), a Sea and Sun Technology PT100 temperature sensor $\left(\sim 0.005^{\circ} \mathrm{C}\right.$ accuracy and better than $\sim 0.001{ }^{\circ} \mathrm{C}$ precision), a Seapoint turbidity meter, a Turner Design CYCLOPS-7 fluorometer for Chl $a$ and an AMT pH sensor (pressure-balanced glass electrode together with an $\mathrm{Ag} / \mathrm{AgCl}$ reference electrode in a plastic housing) with a response time of about 1 second ( $\sim 0.005 \mathrm{pH}$ units precision). From measured conductivity, temperature and pressure, practical salinity was calculated with the UNESCO PSS-78 formulation proposed by Lewis (1980). Density anomaly $\left(\sigma_{\mathrm{T}}\right)$ was calculated from salinity, 
temperature and pressure according to Fofonoff and Millard (1983).

\section{Chlorophyll $a$ correction}

Mean water column (0-9.5 m) Chl a concentrations, derived from CTD profiles, were compared to measurements from GF/F filters of depth-integrated $(0-9.5 \mathrm{~m})$ water samples that were analyzed fluorometrically according to Welschmeyer (1994). A linear regression (adjusted $R^{2}=0.948, \quad n=65, \quad p \leq 0.001$ ) was used to correct the CTD-measured profiles for an offset.

\section{$\mathrm{pH}$ correction}

For potentiometric $\mathrm{pH}$ measurements in seawater, the $\mathrm{pH}$ electrode is recommended to be calibrated with synthetic seawater buffers, namely TRIS (2-amino-2-hydroxymethyl-1,3-propanediol) and 2-aminopyridine adjusted to in situ salinities (Dickson et al. 2007; Dickson 2010). However, this procedure is difficult when the $\mathrm{pH}$ electrode is CTD mounted. Therefore, a different approach was chosen here.

On days $\mathrm{t} 2$ and $\mathrm{t} 13$, depth-integrated $(0-9.5 \mathrm{~m})$ water samples were collected for coulometric DIC and potentiometric TA determinations as described in Dickson et al. (2003) and (2007), respectively. From these measurements, $\mathrm{pH}$ was calculated on the total scale $\left(\mathrm{pH}_{\mathrm{T}}\right)$ with the salinity- and temperature-dependent stoichiometric stability constants for carbonic acid determined by Mehrbach et al. (1973) as refitted by Lueker et al. (2000). Linear regression analyses of calculated $\mathrm{pH}$ and mean water column $\mathrm{pH}$, derived from CTD profiles, on day $\mathrm{t} 2$ (adjusted $R^{2}=$ $0.986, \quad n=3, \quad p=0.054$ ) and day $\mathrm{t} 13$ (adjusted $R^{2}=$ $0.987, \quad n=5, \quad p=<0.001$ ) were used to correct the CTD-mounted $\mathrm{pH}$ sensor measurements and convert them to the total scale.

Potential errors in absolute pH-level determination should not bias the calculated relative changes in $\mathrm{pH}$ and DIC in comparison with starting conditions shown here (but also compare "Carbonate chemistry measurements and calculations" section).

\section{CTD profile visualization}

Vertical resolution of measured CTD profiles was typically on the order of about $4-6 \mathrm{~cm}$ (casts taken at $0.2-0.3 \mathrm{~m} / \mathrm{s}$ ). Each of the profiles was scaled to a uniform resolution of $2 \mathrm{~cm}$ by linear interpolation. Time resolution was on the order of $2 \mathrm{~h}$ with a total of 14 casts in each mesocosm and the fjord. Interpolation for 2D contour plots was done with the MATLAB low-level function contourc at 100 contour levels.
Profiles shown include measured salinity and temperature, calculated density anomaly, corrected Chl $a$ concentrations, corrected $\mathrm{pH}$ on the total scale, and corresponding changes in proton concentrations and calculated DIC. Averages of these parameters, representative for $0.3-11 \mathrm{~m}$ water depth, were calculated by taking the means of the interpolated profiles. As stated above, estimated uncertainties associated with measured changes in $\mathrm{pH}$ and in calculated DIC relative to starting conditions are about 0.01 units and $3 \mu \mathrm{mol} \mathrm{kg}{ }^{-1}$ or less, respectively.

\section{Results}

Temperature, salinity and density characteristics of the enclosed water masses remained relatively constant throughout the measurement period, starting at 19:00 hours on day $\mathrm{t} 3$ and ending at 22:30 hours on the following day (compare Fig. 1). There was no detectable change in overall salinity in any of the mesocosms, suggesting that no water was exchanged between the mesocosms and surrounding seawater and, since there was no rain, evaporation was relatively low (less than 11 per mesocosm). Water temperatures slightly decreased during the night and increased during the day, especially in the upper $3 \mathrm{~m}$ which warmed $\sim 1{ }^{\circ} \mathrm{C}$ during day $\mathrm{t} 4$.

\section{Nutrient utilization and biomass build-up}

Immediately after the first addition of inorganic nutrients on day $\mathrm{t} 0$, the phytoplankton community started taking up the added nitrate and phosphate together with the silicate available. Until the morning of day $\mathrm{t} 3$, about half of the added nitrate and a bit less of the phosphate were utilized. On the morning of day $\mathrm{t} 5$, measured nitrate concentrations in all mesocosms were at the detection limit of $0.1 \mu \mathrm{mol} 1^{-1}$, while measured phosphate concentrations were still at about $0.14 \mu \mathrm{mol} 1^{-1}$. This shows that the period of the diurnal cycle, presented here, coincided with the peak of the phytoplankton bloom which was, according to measured $\mathrm{Chl} a$ concentrations, between the morning of day $\mathrm{t} 4$ and day $\mathrm{t} 5$ (data not shown).

Promoted by sunny conditions on day $\mathrm{t} 4$ and the availability of inorganic nutrients, phytoplankton biomass, measured as Chl $a$ concentrations, steadily increased in all mesocosms (Fig. 2). However, the amounts of Chla produced during this day differed between mesocosms, with about 5.8, 5.3, 5.6, 5.7 and 3.6 $\mu \mathrm{g}^{-1}$ in mesocosms M6, M4, M3, M5 and M2, respectively. Also, Chl $a$ concentrations at the end of day $\mathrm{t} 4$ differed between mesocosms, ranging from $17.2,17.8,16.5,16.2$ to $16.0 \mu \mathrm{g} \mathrm{l}^{-1}$ in mesocosms M6, M4, M3, M5 and M2, respectively. These differences are most likely related to differences in nutrient 

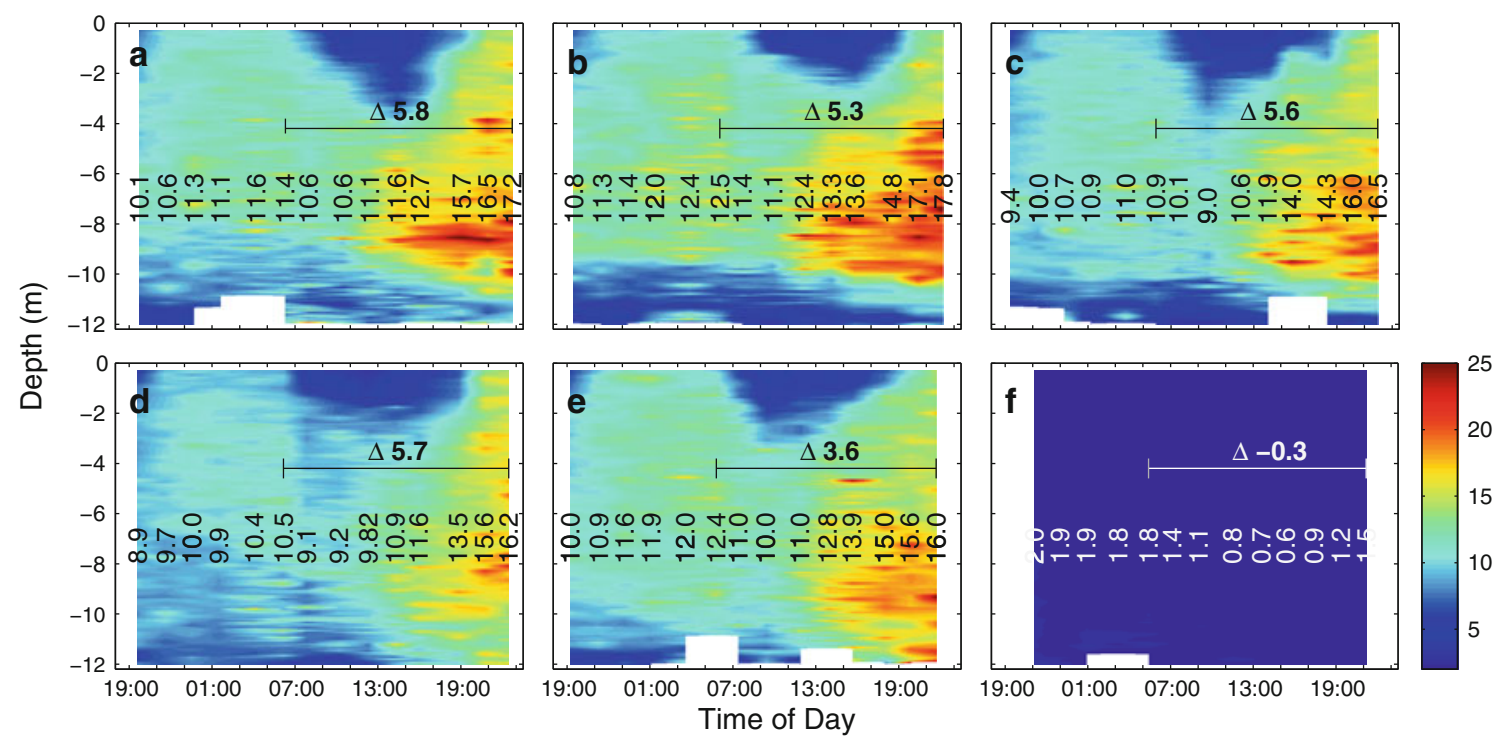

Fig. 2 Measured vertical chlorophyll $a(\mathrm{Chl} a)$ distribution and change with time in mesocosms M6 (a), M4 (b), M3 (c), M5 (d), M2 (e) and the Baltic (f) as measured by a CTD-mounted sensor. These values were compared to depth-integrated $(0-9.5 \mathrm{~m})$ fluorometric Chl $a$ determinations and corrected for an offset (see "Materials and Methods" for details). Vertical numbers denote average concentrations $\left(\mu \mathrm{g}^{-1}\right)$ between 0.3 and $11 \mathrm{~m}$ depth at each cast, while

additions since the volume of the enclosed water differed by up to $20 \%$ between mesocosms, making it difficult to ensure identical nutrient additions. Furthermore, there were also slight differences in the timing of the bloom development. In the surrounding seawater, biomass remained relatively low, fluctuating between $\sim 0.6$ and $\sim 2.0 \mu \mathrm{g} \mathrm{1^{-1 }}$ Chl $a$ (compare Fig. 2f).

Microscopic plankton counts showed that the bloom was dominated by diatoms (D. Rossol, IFM-GEOMAR, pers. comm.) with negligible contributions of calcium carbonate producers. The lack of calcification is consistent with the observation that TA changes throughout the experiment could entirely be explained by dissolved inorganic nutrient utilization and evaporation (as measured by increasing salinity).

Phytoplankton bloom-associated changes in $\mathrm{pH}$ and proton concentrations

Initially, measured $\mathrm{pH}_{\mathrm{T}}$ levels on day $\mathrm{t} 1$ were $7.59,7.66$, 7.78, 7.90 and 8.09 (with an estimated uncertainty of 0.04 units) in mesocosms M6, M4, M3, M5 and M2, respectively, and quite evenly distributed vertically throughout the entire water column (data not shown). Within about three days, following the addition of nutrients, measured $\mathrm{pH}$ increased considerably in all mesocosms (compare Fig. 3), caused by the uptake of dissolved inorganic carbon for photosynthetic $\mathrm{CO}_{2}$ fixation by phytoplankton. horizontal numbers indicate the absolute change in concentrations during the day. Note that the seemingly decreasing concentrations in the upper $\sim 5 \mathrm{~m}$ of the water column starting at dawn until about midday are caused by an attenuation of the chlorophyll fluorescence signal by sunlight and do not reflect actual changes in Chl $a$ concentrations (Falkowski and Kolber 1995; Falkowski and Raven 1997)

Furthermore, the increase was more pronounced in the upper $\sim 6 \mathrm{~m}$ of the mesocosms in comparison with deeper waters. Diurnal variability was considerable, with $\mathrm{pH}$ levels decreasing during the night and increasing during the day. Nevertheless, measured increase during the day was more pronounced than the decrease during the night, meaning that the community was net autotrophic. Averaged over the entire water column, measured $\mathrm{pH}$ changes during daytime of $\mathrm{t} 4$ were highest at the two lowest $\mathrm{pH}$ levels (highest $\mathrm{fCO}_{2}$ ). Toward higher $\mathrm{pH}$ in the remaining three mesocosms, the overall change in water column $\mathrm{pH}$ was less pronounced and lowest in the mesocosm with the highest $\mathrm{pH}$ (lowest $\mathrm{fCO}_{2}$ ) level (compare Fig. 3). Measured variations ranged from 0.227 in mesocosm M4 to 0.143 in M2 (with an estimated uncertainty of less than 0.01 units) and were significantly linearly correlated with $\mathrm{CO}_{2}$ level (adjusted $R^{2}=0.9254, \quad n=5, \quad p=0.0057$ ). Corresponding changes in $\left[\mathrm{H}^{+}\right]_{\mathrm{F}}$ were even more pronounced, being almost three times higher at the highest $\mathrm{CO}_{2}$ level compared to the lowest (adjusted $R^{2}=0.9872, \quad n=5$, $p=0.0004$ ) (compare Fig. 4).

Carbon dioxide gas exchange at the air/sea interface

Measured carbonate chemistry dynamics during the diurnal cycle are driven both by biological activities, such as respiration and photosynthesis, and by physical $\mathrm{CO}_{2}$ exchange 

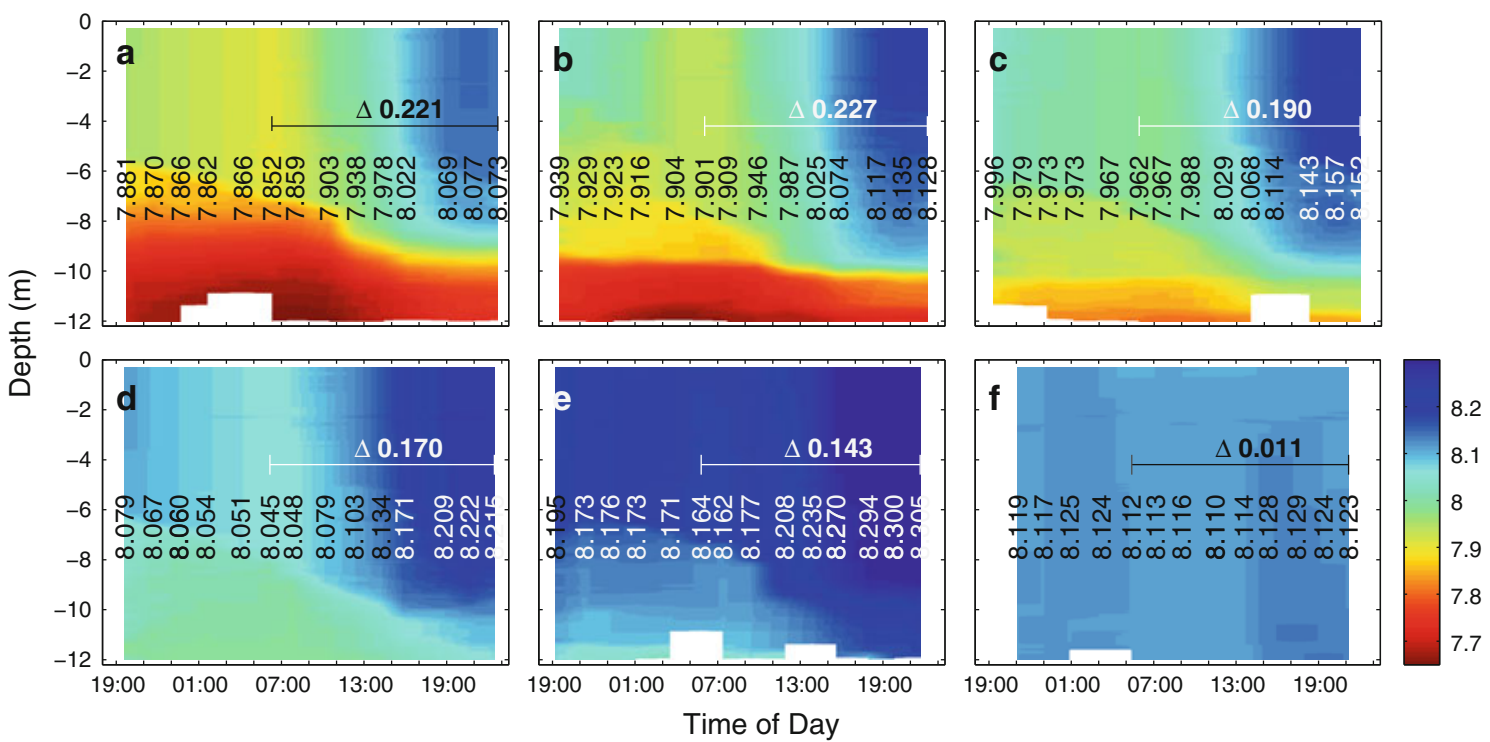

Fig. 3 Vertical $\mathrm{pH}$ distribution and change with time in mesocosms M6 (a), M4 (b), M3 (c), M5 (d), M2 (e) and the Baltic (f) as measured by a CTD-mounted sensor. The $\mathrm{pH}$ is shown on the total scale after correction with calculated $\mathrm{pH}_{\mathrm{T}}$ from measured total alkalinity and dissolved inorganic carbon (see "Materials and Methods" for details). Vertical numbers denote average $\mathrm{pH}$ values between 0.3 and $11 \mathrm{~m}$ depth at each cast, while horizontal numbers indicate the absolute change in $\mathrm{pH}$ during the day

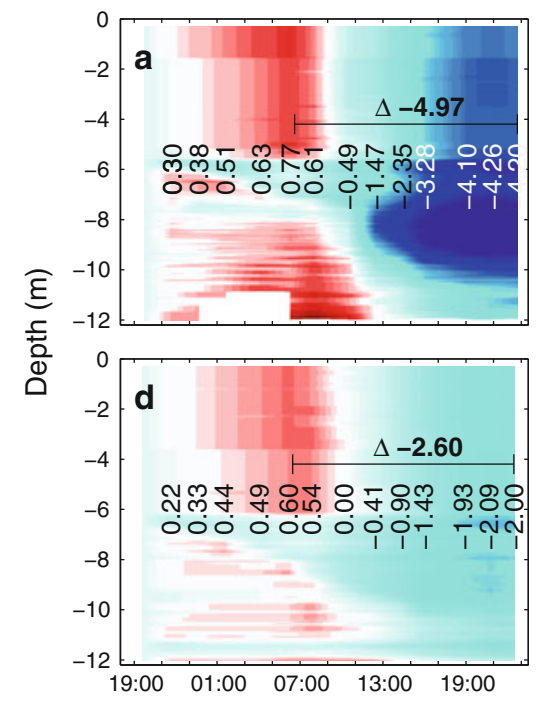

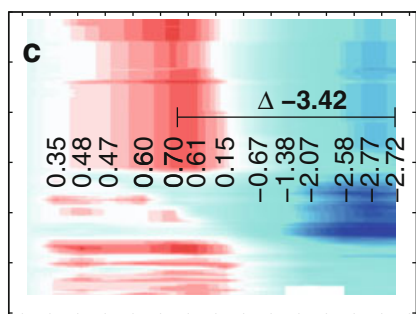

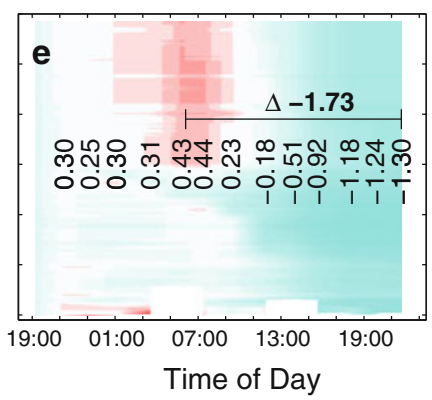

Fig. 4 Calculated vertical concentration changes in free hydrogen ions, $\mathrm{H}_{\mathrm{F}}^{+}\left(\mathrm{nmol} \mathrm{kg}{ }^{-1}\right)$, relative to starting conditions at about 19:00 in mesocosms M6 (a), M4 (b), M3 (c), M5 (d), M2 (e) and the Baltic (f). Concentration changes were calculated from $\mathrm{pH}_{\mathrm{T}}$ profiles (compare Fig. 3 and see "Materials and Methods" for details). Vertical

through the air/sea interface. The impact of air/sea gas exchange on water column DIC inventories, and hence changes in carbonate chemistry speciation, during the diurnal cycle was calculated to be small in comparison with corresponding effects of biological activity, ranging from about 1 to $4 \%$ (see "Appendix “). Note that this corresponds very well with direct gas exchange measurements, made in the mesocosms during another campaign (Czerny et al., in prep.). numbers denote average free hydrogen ion concentration changes in the water column $(0.3$ and $11 \mathrm{~m})$ relative to starting conditions at each cast. Horizontal numbers show the absolute concentration change during the day

Dissolved inorganic carbon concentration changes by respiration and photosynthesis

There were significant changes in DIC concentrations during the night and even more pronounced during the day in all mesocosms (Fig. 5). Respiration of the plankton community during the night increased DIC concentrations by 6.6 to $10.9 \mu \mathrm{mol} \mathrm{kg}{ }^{-1}$, while photosynthesis decreased 
DIC concentrations during the day, ranging from 60.3 in mesocosm M4 to $49.7 \mu \mathrm{mol} \mathrm{kg}^{-1}$ in M2 (with an estimated uncertainty of less than $3 \mu \mathrm{mol} \mathrm{kg}{ }^{-1}$ ). Differences between mesocosms were partly caused by different biomass standing stocks (compare Fig. 2). When normalizing net community production, corrected for air/sea $\mathrm{CO}_{2}$ gas exchange (see "Appendix"), over the entire night/day cycle (26 hours) to Chl $a$ concentrations (at 21:00 hours on day 4 ), there was a statistically significant linear correlation with $\mathrm{CO}_{2}$ with $2.744,2.798,2.652,2.612$ and $2.501 \mu \mathrm{mol} \mathrm{C} / \mu \mathrm{g}$ Chl $a$ per day in mesocosms M6, M4, M3, M5 and M2 at about 675, 605, 520, 420 and $310 \mu$ atm $\mathrm{fCO}_{2}$, respectively (adjusted $R^{2}=0.8353$, $n=5, \quad p=0.019)$. This relation was driven by both trends in Chl $a$-normalized community respiration during the night and net community production during the day.

\section{Discussion}

Diurnal variations in carbonate chemistry speciation, such as $\mathrm{pH}$, driven by biological activity are well documented (compare Introduction). The amplitude of these changes is predicted to increase with increasing future $\mathrm{CO}_{2}$ levels (decreasing seawater $\mathrm{pH}$ ) because of declining seawater buffer capacity [compare e.g., Frankignoulle (1994) and Egleston et al. (2010)]. In the following, we will summarize the impact of various biological processes on seawater carbonate chemistry speciation, compare modeled with measured $\mathrm{CO}_{2}$-dependent changes in amplitude and discuss potential impacts for marine autotrophs.

The changes in carbonate chemistry speciation observed during the diurnal cycle presented here are direct consequences of two biological processes: photosynthesis and respiration. During photosynthesis, dissolved inorganic carbon (DIC) is consumed. Usually associated are increases in total alkalinity (TA) due to charge-balanced uptake of nitrate $\left(\mathrm{NO}_{3}^{-}\right)$and phosphate $\left(\mathrm{PO}_{4}^{3-}\right)$ (Brewer and Goldman 1976; Wolf-Gladrow et al. 2007), although to a much smaller degree. When growth occurs according to the Redfield ratio, $\mathrm{NO}_{3}^{-}$and $\mathrm{PO}_{4}^{3-}$ assimilation generate $0.160 \mathrm{~mol}$ of TA for every mole of DIC consumed. Both changes in DIC and TA shift the carbonate system toward higher $\mathrm{pH}$ levels and lower carbon dioxide $\left(\mathrm{CO}_{2}\right)$ concentrations. When growth relies entirely on ammonia as nitrogen source, uptake in Redfield proportions reduces TA by $0.142 \mathrm{~mol}$ for every mole of DIC consumed. Overall carbonate chemistry speciation changes, however, would be still in the same direction, although slightly smaller in amplitude. Exactly the opposite is happening during respiration (and nutrient remineralization), and its strength in relation to photosynthesis determines whether an ecosystem is net hetero or autotrophic.

Increased changes in carbonate chemistry diurnal variation in a high $\mathrm{CO}_{2}$ world

Despite the fact that photosynthesis and respiration led to similar changes in DIC during daytime, ranging from 49.5
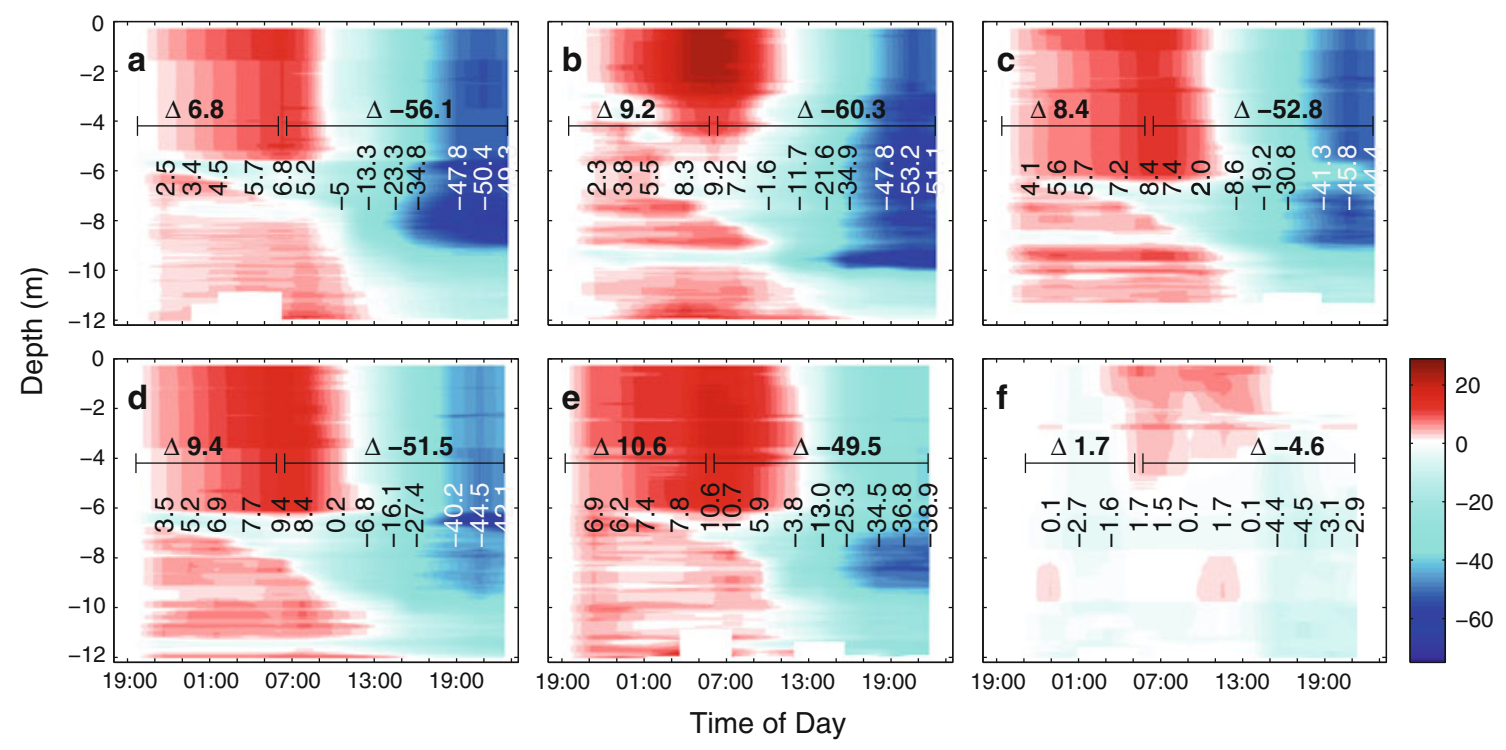

Fig. 5 Calculated vertical concentration changes in dissolved inorganic carbon, DIC $\left(\mu \mathrm{mol} \mathrm{kg}{ }^{-1}\right)$, relative to starting conditions at about 19:00 in mesocosms M6 (a), M4 (b), M3 (c), M5 (d), M2 (e) and the Baltic (f). DIC concentrations were calculated from $\mathrm{pH}_{\mathrm{T}}$ (compare Fig. 3) and measured depth-integrated total alkalinity, TA (see "Materials and Methods" for details). Vertical numbers show average DIC concentration ( $\mu \mathrm{mol} \mathrm{kg}{ }^{-1}$ ) changes relative to starting conditions in the water column $(0.3-11 \mathrm{~m})$ at each cast. Horizontal numbers denote concentration changes by net community respiration and photosynthetic carbon fixation during the night and day, respectively 
to $60.3 \mu \mathrm{mol} \mathrm{kg}{ }^{-1}$ (compare Figs. 5) in all five $\mathrm{CO}_{2}$ treatments of this experiment, diurnal changes in $\mathrm{pH}$ were found to be related to actual in situ $\mathrm{CO}_{2}$ concentrations, being more pronounced at high than at low levels. Changes in free proton concentrations, $\left[\mathrm{H}_{\mathrm{F}}^{+}\right]$were even larger, being almost three times as high at the highest $(675 \mu \mathrm{atm})$ compared to the lowest $(310 \mu \mathrm{atm}) \mathrm{CO}_{2}$ treatment (compare Fig. 4). As stated above, this is the result of lower seawater buffering capacity (Revelle and Suess 1957), meaning that in a high $\mathrm{CO}_{2}$ world for the same amount of primary production, respiration or calcification, associated changes in seawater carbonate chemistry speciation such as $\mathrm{pH}$ and $\mathrm{CO}_{2}$ will be significantly amplified [also compare Frankignoulle (1994) and Egleston et al. (2010)]. Although our observations were made in brackish waters (relatively low salinity and TA), the same applies for more strongly buffered marine waters (higher salinity and TA).

A simple model of net community production was constructed to visualize several aspects influencing natural carbonate chemistry variability in phytoplankton blooms such as carbon dioxide partial pressure, seawater buffer capacity and nutrient availability (Fig. 6). The model combines light- and biomass-dependent DIC uptake for photosynthetic carbon fixation with biomass-dependent release processes of auto- and heterotrophic respiration (see "Appendix" for details). For reasons of simplicity, it is assumed that both processes are $\mathrm{CO}_{2}$ independent (compare Fig. 6a). The model adequately simulates our observations, for instance in $\mathrm{pH}$ on day $\mathrm{t} 4$ (compare Figs. 3 and $6 \mathrm{c}$ ). There are small differences between measured and modeled absolute $\mathrm{pH}$ levels as overall DIC draw-down was not exactly the same in all mesocosms. Nevertheless, the model clearly demonstrates considerably higher $\mathrm{pH}$ and $\mathrm{CO}_{2}$ variability at higher seawater $\mathrm{CO}_{2}$ levels. There are also differences related to seawater buffer capacity. At the study site in the Baltic Sea, variability in $\mathrm{pH}$ and $\mathrm{CO}_{2}$ is higher in comparison with open ocean conditions with higher total alkalinity. Furthermore, DIC draw-down driven by nutrient availability clearly shapes carbonate chemistry variability. In this respect, the vast regions of the oligotrophic open ocean can be considered a relatively stable environment.

Considering simultaneously increasing temperatures together with $\mathrm{CO}_{2}$ levels, the amplitude of diurnal $\mathrm{CO}_{2}$ and $\left[\mathrm{H}_{\mathrm{F}}^{+}\right]$variability would be slightly dampened. This is caused by lower $\mathrm{CO}_{2}$ solubility at higher temperatures resulting in reduced anthropogenic $\mathrm{CO}_{2}$ uptake and therefore diminished reduction in seawater buffer capacity. This effect, however, will be relatively small. For a temperature increase of $3{ }^{\circ} \mathrm{C}$, the decrease in amplitude would be less than $10 \%$ (data not shown).

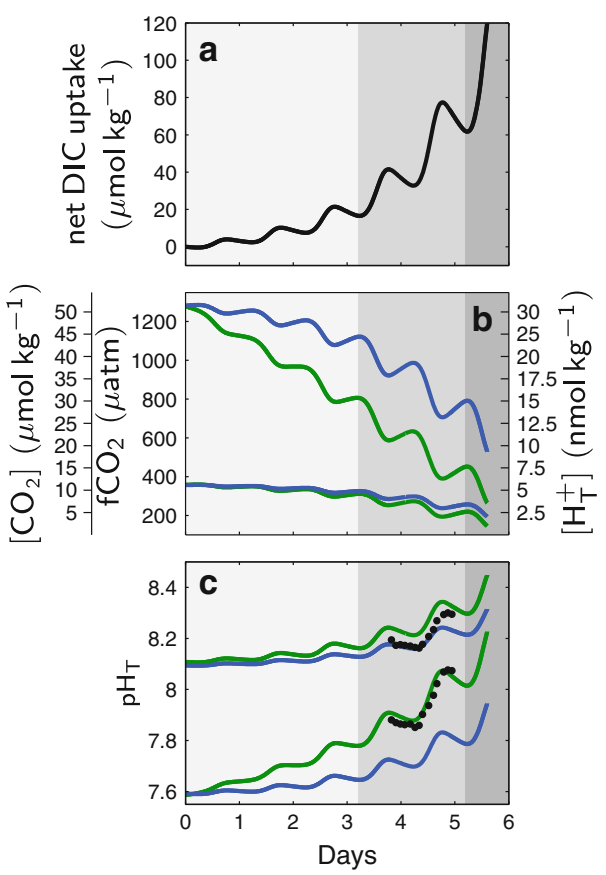

Fig. 6 Modeled net community utilization of dissolved inorganic carbon, DIC (a) and subsequent changes in proton and carbon dioxide concentration and fugacity, $\mathrm{fCO}_{2}(\mathbf{b})$, and $\mathrm{pH}$ on the total scale (c) in the first 5 days following nutrient addition. While green lines denote changes at salinity and carbonate chemistry conditions in our coastal setting, the blue lines are for open ocean conditions with a salinity and total alkalinity of 33 and $2305 \mu \mathrm{mol} \mathrm{kg} \mathrm{kg}^{-1}$, respectively. Black dots mark measured depth-integrated $\mathrm{pH}$ values in mesocosm M6 and M2 (compare Fig. 3). The light, intermediate and dark gray areas highlight the magnitude of changes expected in waters with increasing nutrient and hence DIC utilization (compare a), when moving from oligotrophic open ocean to eutrophic coastal conditions

$\mathrm{CO}_{2}$-dependent carbon fixation

In a previous mesocosm experiment, net photosynthetic carbon uptake was enhanced at elevated seawater $\mathrm{CO}_{2}$ concentration (Riebesell et al. 2007). For the same amount of inorganic nutrients taken up, more DIC was drawn down by the plankton community leading to changes in the stoichiometry regarding carbon to nutrient utilization (Bellerby et al. 2008). When normalizing carbon uptake to phytoplankton biomass, a significant trend of higher rates toward elevated $\mathrm{CO}_{2}$ is also evident in this study. Chlorophyll $a$-normalized net community DIC uptake, corrected for physical air/sea gas exchange, was about $10 \%$ higher at an $\mathrm{fCO}_{2}$ of about $675 \mu \mathrm{atm}$ compared to $310 \mu \mathrm{atm}$. The magnitude of this response is slightly lower than that described previously (Riebesell et al. 2007), yet indicating that this could be a common feature in coastal plankton communities. About half of the overall response was due to changes in nighttime respiration, being reduced at higher $\mathrm{CO}_{2}$ levels (compare Figs. 2 and 5). $\mathrm{CO}_{2}$-dependent changes in dark respiration have also been described for 
mono-specific diatom cultures grown at various carbon dioxide concentrations, but there seem to be species-specific differences ( $\mathrm{Hu}$ and $\mathrm{Gao} 2008)$.

It is noted that there are uncertainties associated with our observation of higher $\mathrm{Chl} a$-normalized net community production at elevated $\mathrm{CO}_{2}$. They are related to our air/sea gas exchange estimate and to uncertainties in changes of measured $\mathrm{pH}$ and calculated DIC. The latter should rather increase scatter in the data than produce trends as uncertainties in calculated DIC changes are independent of $\mathrm{CO}_{2}$ level. Uncertainties in air/sea gas exchange, however, could cause the observed relationship. Although our estimates compare well with direct measurements of $\mathrm{CO}_{2}$ gas exchange during another mesocosm campaign (Czerny et al., in prep), if underestimated by a factor of two, there would be no significant effect of $\mathrm{CO}_{2}$ on $\mathrm{Chl} a$-normalized net community DIC uptake.

In any case, the phenomenon of enhanced DIC consumption by marine plankton communities would further add to enhanced amplitudes in carbonate chemistry speciation changes at elevated $\mathrm{CO}_{2}$. An increase in DIC utilization by $10-20 \%$ would increase the amplitude in carbonate chemistry speciation changes by a similar magnitude.

\section{Potential implications for marine phytoplankton}

Increasing concentrations of $\mathrm{CO}_{2}$ and $\mathrm{H}_{\mathrm{F}}^{+}$, together with amplitude variability, could affect various phytoplankton communities differently. It could be argued that communities adapted to considerable natural variability in today's eutrophic regions will have no problems with increasing absolute values in $\mathrm{CO}_{2}$ and $\mathrm{H}_{\mathrm{F}}^{+}$[compare Joint et al. (2010)]. However, there will also be a substantial increase in $\mathrm{CO}_{2}$ and $\mathrm{H}_{\mathrm{F}}^{+}$variability, considerably increasing upper and lower seasonal and diurnal boundaries for $\mathrm{CO}_{2}$ and $\mathrm{H}_{\mathrm{F}}^{+}$ (compare Fig. 6). How phytoplankton species in these regions will react to this combined change is difficult to predict. For instance, while the operation of carbon-concentrating mechanisms (CCMs) could be advantageous to quickly balance carbon demand with supply during diurnal $\mathrm{CO}_{2}$ variability, the competitive advantage of concentrating $\mathrm{CO}_{2}$ intracellularly could be lost at higher absolute seawater $\mathrm{CO}_{2}$ levels.

The response of phytoplankton communities in the oligotrophic open ocean, however, appears more straightforward to forecast. Here, any future $\mathrm{CO}_{2}$ and $\mathrm{H}_{\mathrm{F}}^{+}$levels will be far beyond natural variability of today's ocean (compare Fig. 6). This could favor less sensitive species and impact community composition.

Acknowledgments We thank Tim Boxhammer, Jan Büdenbender, Michael Sswat, Victor Stiebens and Sandra Vogel for helping with CTD operation, Jan Czerny, Sebatian Krug and Martin Sperling for diving support and Sebastian Fessler and Arne Körtzinger for coulometric dissolved inorganic carbon measurements. Financial support was provided by the BMBF (grant SOPRAN FKZ 03F0462A).

Open Access This article is distributed under the terms of the Creative Commons Attribution License which permits any use, distribution, and reproduction in any medium, provided the original author(s) and the source are credited.

\section{Appendix}

Air/sea gas exchange calculations

Air/sea gas exchange calculations of $\mathrm{CO}_{2}$ and $\mathrm{O}_{2}$ in the mesocosms rely on the exact knowledge of the concentration gradient between seawater and overlying air and wind speed which directly scales with the respective flux. Although the wind was blowing during the diurnal cycle (days $\mathrm{t} 3-\mathrm{t} 4$ ) with an average of about $5.1 \mathrm{~m} / \mathrm{s}$ (measured a few nautical miles away at $35 \mathrm{~m}$ height at the Kiel lighthouse), there was probably almost no wind stress inside the mesocosms because the bags extended to about $1.5 \mathrm{~m}$ above the water surface and were covered with a plastic roof further reducing the air exchange [for details, see Riebesell et al., in prep.]. However, air/sea gas exchange is not driven by wind speeds per se but by seawater boundary layer surface texture, modulated by wave action. Since waves were passing through the mesocosms, a windspeed close to $0 \mathrm{~m} / \mathrm{s}$ for gas exchange calculations would underestimate the actual fluxes. Therefore, we used the decline in measured depth-integrated $\mathrm{O}_{2}$ concentrations in the post-bloom phase on days $\mathrm{t} 5$, $\mathrm{t} 9$ and $\mathrm{t} 11$ to derive a phenomenological wind speed. The assumption made here is that changes in seawater oxygen concentrations were dominated by physical gas exchange and biological processes were negligible. This is based on the observation that seawater $\mathrm{CO}_{2}$ partial pressures in all mesocosms during this phase were relatively small (data not shown), indicating that photosynthetic carbon dioxide consumption and oxygen evolution were equaled by respiratory carbon dioxide release and oxygen consumption. In essence, the wind speed for calculating the transfer velocity for oxygen $\left(k_{\mathrm{O}_{2}}\right.$ given in $\left.\mathrm{cm} / \mathrm{h}\right)$ as described in Wanninkhof (1992) was adjusted to fit the measured changes in seawater oxygen concentrations $\left(\frac{\mathrm{d}\left[\mathrm{O}_{2}\right]}{\mathrm{d} t}\right)$ with

$$
\begin{aligned}
k_{O_{2}}= & {\left[2 . 5 \left(0.5246+1.6256 \times 10^{-2} t c+4.9946\right.\right.} \\
& \left.\left.\times 10^{-4} t c^{2}\right)+0.3 \mathrm{u}^{2}\right](\mathrm{Sc} / 660)^{-1 / 2}
\end{aligned}
$$

and

$\frac{\mathrm{d}\left[\mathrm{O}_{2}\right]}{\mathrm{d} t}=k_{O_{2}}\left(\left[\mathrm{O}_{2}\right]_{\mathrm{sat}}-\left[\mathrm{O}_{2}\right]_{\text {meas }}\right) A /(V \rho)$

with $t c$ and $u$ being the in situ temperature in degrees Celsius and the wind speed in $\mathrm{m} / \mathrm{s}$, respectively, $\mathrm{Sc}$ the 


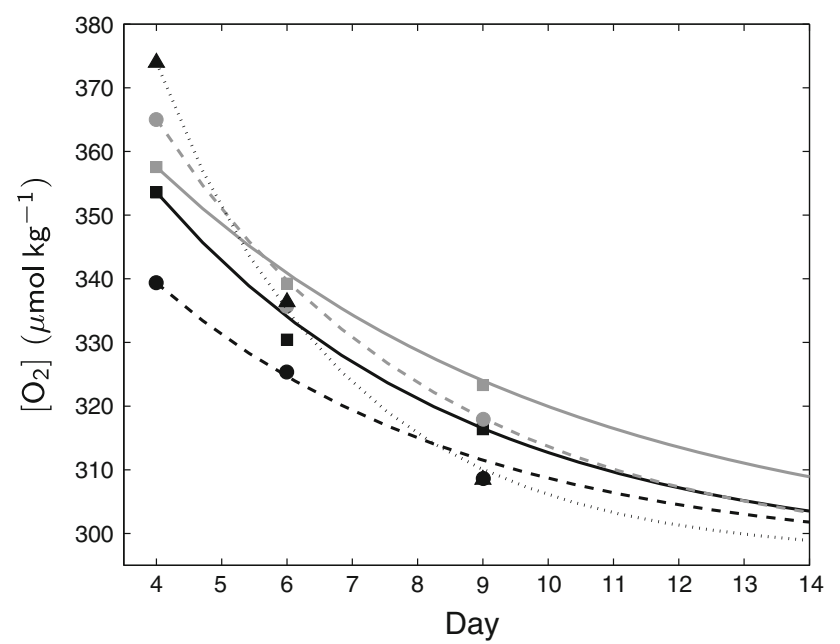

Fig. 7 Temporal changes in measured dissolved oxygen concentrations in mesocosms M6 (black triangles), M4 (gray circles), M3 (black circles), M5 (gray squares) and M2 (black squares) together with fitted concentration changes, leading to phenomenological windspeeds of $6.3,4.9,4.6,3.8$ and $4.6 \mathrm{~m} / \mathrm{s}$, respectively. See "Appendix" for details

temperature- and salinity-dependent Schmidt number given in Wanninkhof (1992), and $\left[\mathrm{O}_{2}\right]_{\mathrm{sat}}$ the temperature- and salinity-dependent oxygen saturation in $\mathrm{mol} / \mathrm{cm}^{3}$ as calculated according to García and Gordon (1992), $\left[\mathrm{O}_{2}\right]_{\text {meas }}$ the measured depth-integrated oxygen concentrations in $\mathrm{mol} / \mathrm{cm}^{3}, A$ the surface area for gas exchange in the mesocosms $\left(31415 \mathrm{~cm}^{2}\right), V$ the seawater volume estimated to be $30,0001, \rho$ the temperature- and salinity-dependent seawater density in $\mathrm{kg} / \mathrm{l}$ given by Millero and Poisson (1981) and $t$ the time in hours. The differential equation 2 was solved numerically with the MATLAB 'ode45' solver (Shampine and Reichelt 1997), by adjusting $u$ to best fit the oxygen changes in the mesocosms during the period from day $\mathrm{t} 4$ to day $\mathrm{t} 9$. The resulting phenomenological wind speeds were ranging between 3.8 and $6.3 \mathrm{~m} / \mathrm{s}$ (compare Fig. 7), considerably lower than measured average wind speeds at $35 \mathrm{~m}$ height at the Kiel lighthouse of $8.3 \mathrm{~m} / \mathrm{s}$. Adopting the median of $4.6 \mathrm{~m} / \mathrm{s}$ for the $\mathrm{CO}_{2}$ flux calculations between days $\mathrm{t} 3$ and t4 (measured windspeed of $5.1 \mathrm{~m} / \mathrm{s}$ ) could therefore be considered a conservative approach. DIC concentration changes during the fourteen measurements of the diurnal cycle due to air/sea gas exchange were calculated as

$\sum_{i=1}^{14}=k_{\mathrm{CO}_{2}} \mathrm{~K}_{0}\left(\mathrm{fCO}_{2}\right.$ air $\left.-\mathrm{fCO}_{2 \mathrm{sea}_{\mathrm{i}}}\right) A /(V \rho) t$

and

$\begin{aligned} k_{\mathrm{CO}_{2}}= & {\left[2.5\left(0.5246+1.6256 \times 10^{-2} t c+4.9946\right.\right.} \\ & \left.\left.\times 10^{-4} t c^{2}\right)+0.3 u^{2}\right](\mathrm{Sc} / 660)^{-1 / 2}\end{aligned}$ with $k_{\mathrm{CO}_{2}}$ being the transfer velocity $(\mathrm{cm} / \mathrm{h})$ for $\mathrm{CO}_{2}$ calculated according to Wanninkhof (1992) with $t c$ set to $13{ }^{\circ} \mathrm{C}$ and $u$ to $4.6 \mathrm{~m} / \mathrm{s}$, and $\mathrm{K}_{0}$ the solubility of $\mathrm{CO}_{2}$ in seawater (Weiss 1974) given in mol kg ${ }^{-1} \mathrm{~atm}^{-1}, f C O_{2}$ air and $\mathrm{fCO}_{2 \text { seai }}$ the carbon dioxide fugacity in air and seawater, respectively, at measurement number $i$, and $t$ the time between two consecutive measurements $(2 \mathrm{~h})$.

The calculated contribution of air/sea gas exchange to diurnal variations in DIC concentration was $2.1,1.3,0.65$, -0.23 and $-1.2 \mu \mathrm{mol} \mathrm{kg}^{-1}$ in mesocosms M6, M4, M3, M5 and M2, respectively.

\section{Model parameterization}

The model is one of the simplest representations of lightand biomass-dependent DIC utilization, and biomassdependent release by auto- and heterotrophic respiration as $\frac{\mathrm{dC}}{\mathrm{dt}}=\mathrm{k} \sin (\pi t)^{4} \mathrm{C}-g \mathrm{C}$

with $\mathrm{C}$ denoting carbon biomass $\left(\mu \mathrm{mol} \mathrm{kg}{ }^{-1}\right)$ and $t$ time (d), $\mathrm{k}$ representing maximum community gross carbon fixation rate at maximum light level $\left(\mathrm{d}^{-1}\right)$, g comprising all carbon-release processes $\left(\mathrm{d}^{-1}\right)$ and $\sin (\pi t)^{4}$ simulating natural diurnal light availability. The model was initialized with measured values for total alkalinity and $\mathrm{pH}$ (from mesocosm M6 and M2), initial autotrophic carbon biomass ( $\left.4 \mu \mathrm{mol} \mathrm{kg}{ }^{-1}\right)$, and $\mathrm{k}$ and $\mathrm{g}$ (3.15 and 0.6 , respectively) to best fit our observations starting at the end of day t 3 to the end of day $t 4$ (compare Fig. 3). Carbonate chemistry speciation was calculated as described in the "Carbonate chemistry measurements and calculations" section from TA and DIC, corrected for $\mathrm{CO}_{2}$ gas exchange (see above). The differential equation 5 was integrated numerically with the MATLAB ode 45 solver.

\section{References}

Bellerby RGJ, Schulz KG, Riebesell U, Neill C, Nondal G, Heegaard E, Johannessen T, Brown KR (2008) Marine ecosystem community carbon and nutrient uptake stoichiometry under varying ocean acidification during the PeECE III experiment. Biogeosci 5:1517-1527

Brewer PG, Goldman JC (1976) Alkalinity changes generated by phytoplankton growth. Limnol Oceanogr 21:108-117

Delille B, Borges AV, Delille D (2009) Influence of giant kelp beds (Macrocystis pyrifera) on diel cycles of $\mathrm{pCO}_{2}$ and DIC in the Sub-Antarctic coastal area. Estuar Coast Shelf Sci 81:114-122

Dickson AG, Afghan JD, Anderson GC (2003) Reference materials for oceanic $\mathrm{CO}_{2}$ analysis: a method for the certification of total alkalinity. Mar Chem 80:185-197

Dickson AG (2010) The carbon dioxide system in sea water: equilibrium chemistry and measurements. In: Riebesell U, Fabry VJ, Gattuso J.-P (eds). Guide to best practices in ocean 
acidification research and data reporting. http://wwwepocaprojecteu/indexphp/Home/Guide-to-OA-Research/

Dickson, AG, Sabine, CL, Christian, JR (eds) (2007) Guide to best practices for ocean $\mathrm{CO}_{2}$ measurements. PICES Special Publication 3

Dore JE, Lukas R, Sadler DW, Church MJ, Karl DM (2009) Physical and biogeochemical modulation of ocean acidification in the central North Pacific. Proc Natl Acad Sci USA 106:12,235-12,240

Egleston ES, Sabine CL, Morel FMM (2010) Revelle revisited: buffer factors that quantify the response of ocean chemistry to changes in DIC and alkalinity. Glob Biogeochm Cycle 24, doi: 10.1029/2008GB003407

Engel A, Zondervan I, Aerts K, Beaufort L, Benthien A, Chou L, Delille B, Gattuso JP, Harlay J, Heemann C, Hoffmann L, Jacquet S, Nejstgaard J, Pizay MD, Rochelle-Newall E, Schneider U, Terbrueggen A, Riebesell U (2005) Testing the direct effect of $\mathrm{CO}_{2}$ concentration on a bloom of the coccolithophorid. Emiliania huxleyi in mesocosm experiments. Limnol Oceanogr 50:493-507

Falkowski PG, Kolber Z (1995) Variations in chlorophyll fluorescence yields in phytoplankton in the world oceans. Aust J Plant Physiol 22:341-355

Falkowski PG, Raven J (1997) Aquatic photosynthesis. Blackwell Science, Malden (MA) USA

Farquhar GD, Fasham MJR, Goulden M, Heimann M, Jaramillo VJ, Kheshgi HS, Le Qu C, Scholes RJ, Wallace DWR (2001) The Carbon Cycle and Atmospheric Carbon Dioxide. In: Houghton JT, Ding Y, Griggs DJ, Noguer M, van der Linden PJ, Dai X, Maskell K, Johnson CA (eds). Climate change 2001: The scientific basis. Contribution of Working Group I to the Third Assessment Report of the Intergovernmental Panel on Climate Change. Cambridge University Press, Cambridge and New York, NY

Fofonoff NP, Millard Jr RC (1983) Algorithms for the computation of fundamental properties of seawater. UNESCO techn pap mar sci 44

Frankignoulle M (1994) A complete set of buffer factors for acid/base $\mathrm{CO}_{2}$ system in seawater. J Mar Syst 4:111-119

Frankignoulle M, Bouquegneau JM (1990) Daily and yearly variations of total inorganic carbon in a productive coastal area. Estuar Coast Shelf Sci 30:79-89

Frankignoulle M, Gattuso JP, Biondo R, Bourge I, Copin-Montégut G, Pichon M (1996) Carbon fluxes in coral reefs. II. Eulerian study of inorganic carbon dynamics and measurement of air-sea $\mathrm{CO}_{2}$ exchanges. Mar Ecol Progr Ser 145:123-132

García HE, Gordon LI (1992) Oxygen solubility in seawater: Better fitting equations. Limnol Oceanogr 37:1307-1312

Gattuso J.-P, Lee K, Rost B, Schulz KG (2010) Approaches and tools to manipulate the carbonate chemistry. In: Riebesell U, Fabry VJ, Gattuso J.-P (eds). Guide to best practices in ocean acidification research and data reporting. http://wwwepocaprojecteu/indexphp/Home/Guide-to-OA-Research/

González-Dávila M, Santana-Casiano JM (2011) Sea surface and atmospheric fco 2 data measured during the estoc time series cruises from 1995-2009. http://cdiacornlgov/ftp/oceans/ESTOC_ data/ Carbon dioxide information analysis center, Oak Ridge National Laboratory, US Department of Energy, Oak Ridge, Tennessee doi:10.3334/CDIAC/otg.TSM_ESTOC

Hansen HP, Koroleff F (1999) Determination of nutrients. In: Grasshoff K, Kremling K, Ehrhardt M (eds) Methods of seawater analysis, 3rd edn, Wiley VCH, Weinheim, pp 159-228

$\mathrm{Hu} \mathrm{H}$, Gao K (2008) Impacts of $\mathrm{CO}_{2}$ enrichment on growth and photosynthesis in freshwater and marine diatoms. Chin J Ocean Limnol 26:407-414
Joint I, Doney SC, Karl DM (2010) Will ocean acidification affect marine microbes? ISME J. doi:10.1038/ismej.2010.79

Lewis EL (1980) The Practical Salinity Scale 1978 and Its Antecedents. IEEE J Ocean Eng OE-5:3-8

Lueker TJ, Dickson AG, Keeling CD (2000) Ocean p $\mathrm{CO}_{2}$ calculated from dissolved inorganic carbon, alkalinity, and equations for $K_{1}$ and $K_{2}$ : validation based on laboratory measurements of $\mathrm{CO}_{2}$ in gas and seawater at equilibrium. Mar Chem 70:105-119

Maberly SC (1996) Diel, episodic and seasonal changes in $\mathrm{pH}$ and concentrations of inorganic carbon in a productive lake. Freshw Biol 35:579-598

Manzello DP (2010) Ocean acidification hot spots: Spatiotemporal dynamics of the seawater $\mathrm{CO}_{2}$ system of eastern Pacific coral reefs. Limnol Oceanogr 55:239-248

Mehrbach C, Culberson CH, Hawley JE, Pytkowicz RM (1973) Measurements of the apparent dissociation constants of carbonic acid in seawater at atmospheric pressure. Limnol Oceanogr 18:897-907

Millero FJ, Poisson A (1981) International one-atmosphere equation of state for sea water. Deep Sea Res 28:625-629

Ohde S, van Woesik R (1999) Carbon dioxide flux and metabolic processes of a coral reef, Okinawa. Bull Mar Sci 65:559-576

Revelle R, Suess H (1957) Carbon dioxide exchange between atmosphere and ocean and the question of an increase of atmospheric $\mathrm{CO}_{2}$ during the past decades. Tellus 9:18-27

Riebesell U, Schulz KG, Bellerby RGJ, Botros M, Fritsche P, Meyerhöfer N, Neill C, GN , Oschlies A, Wohlers J, Zöllner E (2007) Enhanced biological carbon consumption in a high $\mathrm{CO}_{2}$ ocean. Nature 450:545-548. doi:10.1038/nature06267

Rost B, Riebesell U, Burkhardt S, Sültemeyer D (2003) Carbon acquisition of bloom-forming marine phytoplankton. Limnol Oceanogr 48:55-67

Schulz KG, Riebesell U, Bellerby RGJ, Biswas H, Meyeröfer M, Müller MN, Egge JK, Nejstgaard JC, Neill C, Wohlers J, Zöllner E (2008) Build-up and decline of organic matter during PeECE III. Biogeosci 5:707-718

Schulz KG, Barcelos e Ramos J, Zeebe RE, Riebesell U (2009) $\mathrm{CO}_{2}$ perturbation experiments: similarities and differences between dissolved inorganic carbon and total alkalinity manipulations. Biogeosci 6:2145-2153

Shampine LF, Reichelt MW (1997) The matlab ODE suite. SIAM J Sci Comput 18:1-22

Subramanian B, Mahadevan A (1999) Seasonal and diurnal variation of hydrobiological characters of coastal water of Chennai (Madras), Bay of Bengal. Ind J Mar Sci 28:429-433

Thomsen J, Gutowska MA, Saphörster J, Heinemann A, Trübenbach K, Fietzke J, Hiebenthal C, Eisenhauer A, Körtzinger A, Wahl M, Melzner F (2010) Calcifying invertebrates succeed in a naturally $\mathrm{CO}_{2}$-rich coastal habitat but are threatened by high levels of future acidification. Biogeosci 7:3879-3891

Wanninkhof R (1992) Relationship between wind speed and gas exchange over the ocean. J Geophys Res 97(C5):7373-7382

Weiss RF (1974) Carbon dioxide in water and seawater: the solubility of a non-ideal gas. Mar Chem 2:203-215

Welschmeyer NA (1994) Fluorometric analysis of chlorophyll $a$ in the presence of chlorophyll $b$ and pheopigments. Limnol Oceanogr 39:1985-1992

Wolf-Gladrow DA, Zeebe RE, Klaas C, Körtzinger A, Dickson AG (2007) Total alkalinity: the explicit conservative expression and its application to biogeochemical processes. Mar Chem 106: $287-300$ 